\title{
STUDY ON FISHING CRAFT AND GEARS OPERATED IN NANAK SAGAR RESERVOIR, UTTARAKHAND, INDIA
}

\author{
RAJESH", R. S. CHAUHAN, ASHUTOSH MISHRA and PRIYANKA ARYA \\ College of Fisheries, G. B. Pant University of Agriculture and Technology, Pantnagar (Uttarakhand)
}

\begin{abstract}
Nanaksagar reservoir is situated in between $28^{\circ} 45^{\prime} \mathrm{N}$ latitude and $79^{\circ} 45^{\prime} \mathrm{E}$ longitude in the state of Uttrakhand. The present investigation deals with the various fishing craft and gear adopted for fishery purpose in Nanaksagar reservoir. The passive gear has been widely used in reservoir. Groups of fish species catch composition landed by artisanal fishermen using one traditional non-mechanized craft and five types of gear: gillnets, triangular net, drag net, hooks and line and cast net were observed in the reservoir and studied fish catch composition in relation to fishing gears operated in reservoir to develop gear based management practices to obtain the sustainable yield from large water body. The detailed investigation is documented in the current research paper.
\end{abstract}

Key words : Nanaksagar reservoir, Fishing craft, Fishing gears, Mesh size, Fish catch.

\section{INTRODUCTION}

India is blessed with almost all forms of rich natural resources of water and vast fish diversity. In India aquaculture is the fastest growing sub sector of agriculture. Though India is the second largest producer of fish from culture after the red gi ant China, the quantum of production is substantially low compared to the leader. India has a vast potential in the fisheries sector both in inland, brackish water and marine sector. The Ichthyofauna of freshwater systems of India is extremely diverse. Fishes are important resources worldwide, especially as food. Geo-morphological and hydrological salient feature of Nanak Sagar reservoir are as follows. The reservoir was constructed in the year 1962,area of FRL 4662(ha), type of foundation earthen, total length of the Bundh $19.2 \mathrm{~km}$, top width of the dam 6.0 meter, main rivers joins Devaha and the total catchment's area covering $570 \mathrm{sq} / \mathrm{km}$. In this reservoir, December to June is the important commercial fishing period and fishermen were used passive gear and nets to catch the fishes of reservoir in Tarai region of Uttrakhand. Most of the fishes are captured by gillnets locally known as fansla jal, Drag net (Mahajal) Hooks and line (dori). The river Devaha is the main feeder river for impound the reservoir especially for the purpose of irrigate the agriculture fields as well as for the pisciculture. Nanaksagar reservoir harbours a variety of fish species especially Indian Major carps, Minor carps, catfishes, Murrels, Snakeheads, Exotic fishes and many more variety of species and contributes over a great extent upon the Uttarakhand state inland fish production. Fishing craft and gears adopted in Nanaksagar reservoir were simple tools used by local fisherman for commercial catches of fish production. The craft and gears were mostly old fashioned, indigenous and locally manufactured.

Several researchers work upon the fishing craft and gears used over freshwaters of India and abroad (Gurumayum et al.,2009; Kingdom et al.,2009; Mohammed et al.,2012; Baruah et al.,2013 and Islam et al.,2013). There are number of workers work upon the fishing methods of Indian reservoirs (George et al.,1982; Sakhare,2007; Sugunan,1995; Mathai \&
George,1972 and Vergheese et al.,1982). Unfortunately, the fishing methods used in the Nanaksagar reservoir were not documented ever in the inland fisheries sector of Uttarakhand. The present paper is an attempt to document the fishing craft and gear used in Nanaksagar reservoir.

\section{MATERIAL AND METHODS}

The present investigation of fishing craft and gear was carried out from the period of July,2013-June, 2104. All the relevant data and information regarding the major fishing gears used for catch of fishes by different nets collected by physically sampling month-wise. Based on data base of Department of Fisheries (FFDA) U.S. Nagar, Uttarakhand and personal interaction and interview with fishing contractors and questionnaires with local fishermen's community of Nanaksagar reservoir. Fish catch and fish population were recorded throughout the investigation periods from landing centers locally known as Machhi Jhala. In present study, the fishes were caught by gill net, drag net, cast net, triangular net, hook and lines and brought to the Department of Fishery Biology laboratories of College of Fisheries, Pantnagar for identification. The fishes were preserved by $5 \%$ formalin for the further study. The varieties of fishes caught from the reservoirs were identified following Berg (1947), Day (1878), Jhingran (1991) and Srivastava (2002).

\section{RESULTS AND DISCUSSION}

The present investigation reported that major fishing gear was gill nets with different mesh size locally called as 4 to 12 Angura jal (gill net) which are actual measured in terms of mesh size (75-200 mm) operated in Nanaksagar reservoirs . Drag net locally known as mahajal was having mesh size ranged from $60-80 \mathrm{~mm}$. This net was generally operated by 15-20 fishermen's for catch of all kind of fishes. Cast net (mesh size 20-30 mm) and Hook and line (7-12 No. with 100300 iron hooks) are locally known as Jhumari jal and Kanta (dori) respectively used for catch of cat fishes. Except mon- 
soon season, fishing in Nanaksagar reservoir was conducted by the contractors throughout the mentioned period of years. The commonly used gears are Gill net (fansla jal), Drag net (Mahajal), hooks and line (dori) and cast net. Nanaksagar reservoir was constructed in the year 1962 across the rivers Devaha and Kamini which received number of rivulets during the course of their water flow from North-South. The reservoir was constructed with the prime objectives of flood control and storing water for irrigation purpose. Nanaksagar reservoir is roughly conical in shape with an irregular shore line. The maximum height of the dam is 16.50 meter and it has 6.0 meter road on the top width of the Dam. The reservoir has a total length of Bundh $19.02 \mathrm{~km}$, mean depth $3.0 \mathrm{~m}$. The catchment's areas of the Nanaksagr dam are $570.0 \mathrm{~km}^{2}$. The water spread area of this manmade reservoir is 4662 (ha). It is also a main water body for commercial fish production which is managed by state fisheries department of Uttarakhand. It shows a variety of Icthyofauna Catla catla, Labeo rohita, Labeo gonius, Labeo calbasu, Labeo bata, Cirrhinus mrigala, Cirrhinus reba, Cyprinus carpio communis, Wallago attu, Ompok pabo, Channa striatus, Heteropneustes fossilis, Mystus tengra, Notopterus notopterus are the chief species and other miscellaneous fish species Mastacembalus armatus, Nemacheilus botia, Colisa fasciatus, Gudusia chapra, Xenetedon cancilla, Puntius spp. reported in the Nanaksagar reservoir. The satellite image of Nanaksagar res- ervoir is shown in Plate. 1 and description of the satellite data in Table.3. During present investigation one craft and five gears were observed in Nanaksagar reservoir. The single craft was a wooden, non-mechanized boat while gears were Gill net, triangular net, drag net, cast net, hooks and lines. Drag net is mainly used because of the maximum catch efficiency (Joshi, 2011), but the problem with drag net is trapping of weed fishes. Drag net (100-300 m length and 3-6 m width) is generally used in summer season when water level is low. Gill net with mesh size of 40,50 and $60 \mathrm{~mm}$ mesh size bar nets was found to be more effective for commercial fishing in Tungabhadra, Hirakund and Govindsagar reservoirs (David and Rajgopal,1978). The different fishing gears along with the fish species caught by them are listed in Table. 1 and groups of fish species in Table.2. In the present study it was observed that the only one type of fishing craft was used and it is a flat timber wooden boat and sides were covered with aluminum sheets and Non- mechanized boats manufactured by local professional carpenters . The length of boat is ranged from 4- $6 \mathrm{~m}$ and width 1-2 m (Kumar and Kumar,2013) investigated in Dhaura reservoir that the length of the boat is about 7-11 meters and width is about 1-2 meter and gill net is most common fishing gear used by the fishermen. Wooden boats are used for fishing in a number of reservoirs, especially in the North India. Flat-bottom, locally fabricated boats ranging in length from 3-7 m are used in Kyrdemkulai, Hirakud, Malampuzha,

Table. 1 Fishing gear used in Nanaksagar reservoirs in relation to fish catch.

\begin{tabular}{llcl}
\hline Fishing gear & Local name & Mesh size & Fish catch composition \\
\hline Gill net & Fansla Jal & $75-200 \mathrm{~mm}$ & Indian major carps, Minor carps and large cat fishes \\
Triangular Net & Besar Jal & $15-20 \mathrm{~mm}$ & Weed fishes and specially (Gudusia chapra) \\
Drag Net & Mahajal & $60-80 \mathrm{~mm}$ & Major carps, Minor carps and cat fishes (all kind of fishes) \\
Cast Net & Jhumari Jal & $20-30 \mathrm{~mm}$ & Major \& Minor carps, minnows and cat fishes \\
Hooks and line & Dori & $7-12$ No. $(100-300$ iron hooks) & Cat fishes, Balm and Murrels \\
\hline
\end{tabular}

Table. 2 Groups of fish species of Nanaksagar reservoir.

\begin{tabular}{ll}
\hline Groups & Genera/Species catch composition \\
\hline Major carps & Catla catla \\
& Labeo spp. \\
& Cirrhinus spp. \\
& Cyprinus carpio \\
Cat fishes & Wallago attu \\
& Heteropneustes fossilis \\
& Clarius batrachus \\
& Mystus spp. \\
& Channa spp. \\
Minor carps & Labeo gonius \\
& L.calbasu \\
Miscellaneous & Xenetedon cancilla \\
& Notopterus notopterus \\
& Oreochromis niloticus \\
& Mastacembalus spp. \\
& Nemacheilus botia \\
& Colisa fasciatus \\
& Gudusia chapra \\
Uneconomical fishes & Puntius spp. \\
& Chanda spp. \\
& Chela spp.
\end{tabular}

Table. 3 Description of the Satellite data (IRS LISS III).

\begin{tabular}{|c|c|}
\hline S. Resolution & Description \\
\hline 1. Spatial resolution & $23.5 \mathrm{~m}$ \\
\hline \multirow[t]{4}{*}{ 2. Spectral resolution } & Green $\quad 0.52-0.59$ microns \\
\hline & $0.62-0.68$ microns \\
\hline & $0.77-0.86$ microns \\
\hline & SWIR $1.55-1.70$ microns \\
\hline 3. Temporal resolution & 24 Days \\
\hline
\end{tabular}

Gobindsagar, Gandhisagar and Rihand (De Silva,2009). A plank-built, flat-bottom canoe of 2-3 $\mathrm{m}$ in length is the most popular fishing craft of Gandhisagar.

Mechanized boats are not used in reservoir fishing to any appreciable extent. Dugout canoes, carved out of palm trees are used in Yerrakalava reservoir. The gill net was the most favored fishing gear employed in Nanaksagar reservoir. It was made of nylon twine and was about 50-100 m long and 1.5-4 m wide. Nanaksagar reservoir shows numerous indigenous as well as exotic fish species and in terms of commercial fisheries. It is one of the important water bodies of Uttarakhand state as well as northern part of India. 


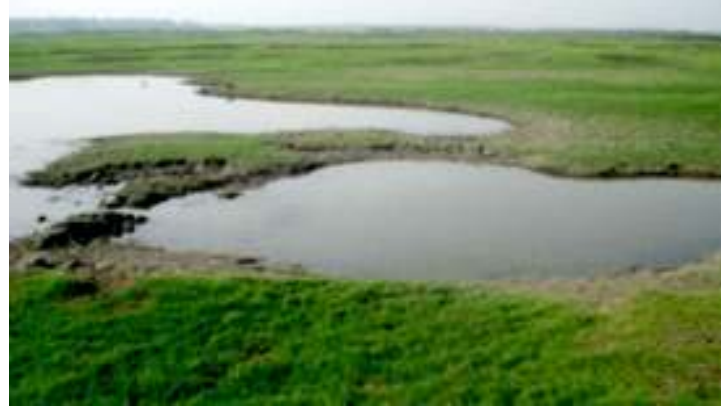

Coves of Nanaksagar

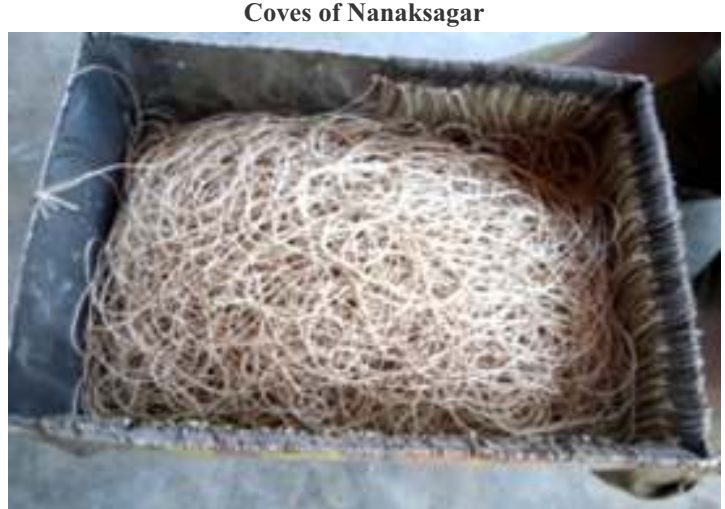

Hooks and Line (Dori)

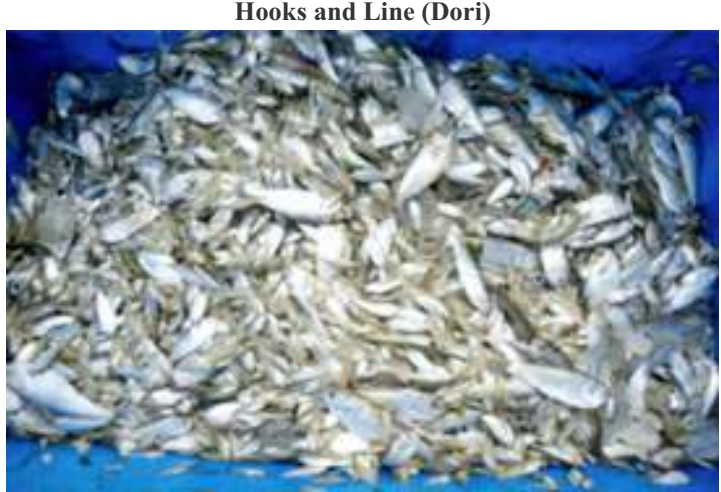

Miscellaneous fish catch

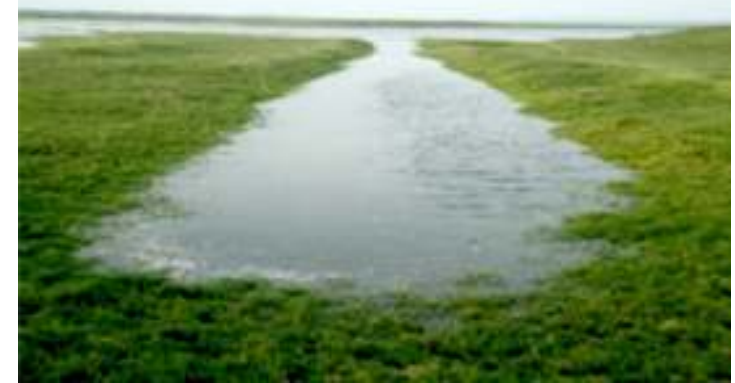

Arms of Nanaksagar

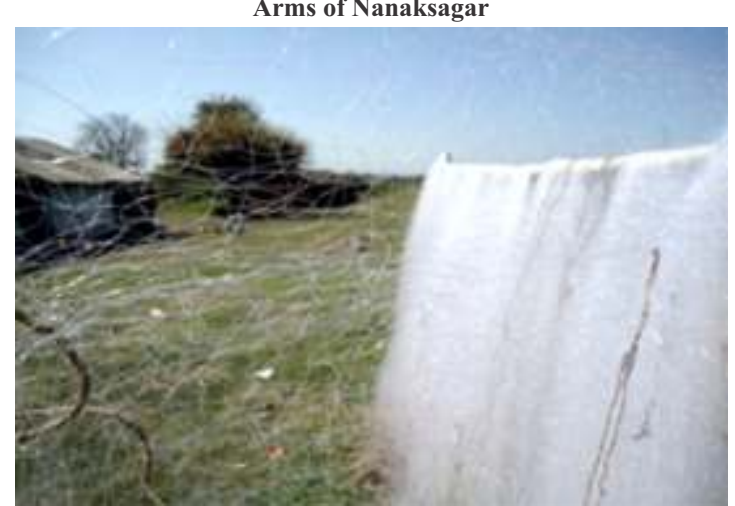

Gillnet variations

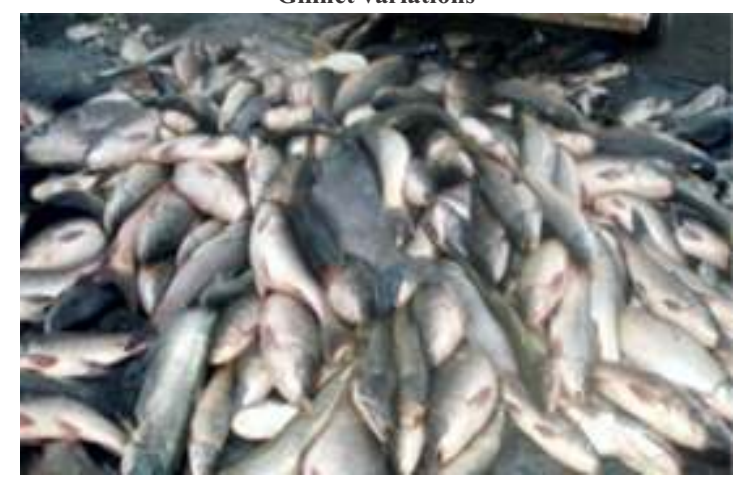

Major carps mixed catch

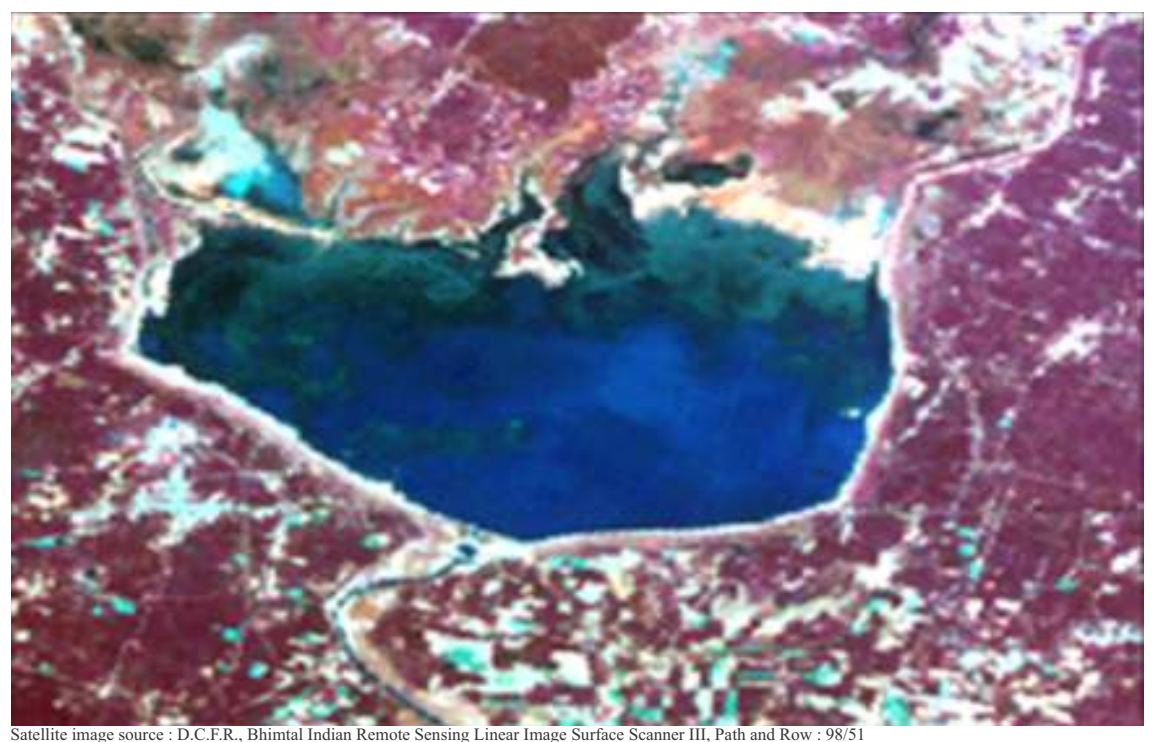

Plate. 1 Nanaksagar reservoir

Peer Reviewed Research Journal : National Journal of Life Sciences, Vol. 17(1) : 2020 
To achieve commercial yield of fish production in reasonable period following measure should be implemented: boat should be regularly checked and repaired whenever required and over age boats should be rejected, Unauthorized poaching of fish species should be totally banned, local fishermen should aware about the use of well known modern fishing equipments and crafts, proper training of modern fishing methods should be provided for the fishermen's community by Government authorities of reservoir to get judicious catch.

\section{ACKNOWLEDGMENTS}

The authors are grateful to the authorities of university, Dean PGS, Prof. \& HOD, Department of Fisheries Resource Management and Dean College of Fisheries for granting permission and his constant encouragement and valuable guidance in carrying out the study. The help rendered by local fishermen, fishing contractors Mr. A. P. Singh and Department of Fisheries, U.K. is duly acknowledged.

\section{REFERENCES}

Baruah, D.; Dutta, A. and Pravin, P. (2013). Traditional Fish Trapping Devices and Methods in the Brahmaputra Valley of Assam. Indian J. Traditional Knowledge, 12(1): 123-129.

Berg, L. S. (1947). Classification of fishes both recent and fossil. Traveaux Follett's Michigem Bookstore, pp. 87-517.

David, A. and Rajgopal, K. V. (1978). Experimental fishing and observation on commercial fishing methods. In : Proc. Ecology and Fisheries of Fresh Water Reservoir. CIFRI, Barrackpore, pp. 503-516.

Day Francis, (1878). The fishes of India. William Dawson \& Sons Ltd., London, p. 703.

De Silva, S. S. and Amarasinghe, U S. (2009). Status of reservoir fisheries in five Asian countries. NACA Monograph No. 2. Network of Aquaculture Centers in Asia-Pacific, Bangkok, Thailand, p. 113.

George V. C.; Dawson, P.; Khan, A. A. and Verghese, M. D. (1982). Experimental trawling in Hirakund reservoir. Fish Technol., 19(1) : 15-18.

Gurumayum, S. D. and Choudhary, M. (2009). Fishing methods in the rivers of Northeast India. Indian J. Traditional Knowledge, 8(2) : $237-$ 241.

Islam, M. R.; Das, B.; Baruah, D.; Biswas, S. P. and Gupta, A. (2013). Fish diversity and fishing gears used in the Kulsi river of Assam. Annals of Biological Research, 4(1): 289-293.

Jhingran, V. G. (1991). Fish and fisheries of India. Hindustan Publishing Corporation, India, p. 72.

Jhoshi, Pramod (2011). Fishes catch statistics in relation to nets and gear used. J. Exp. Zool. India, 14(2): 591-593.

Kingdom, T. and Kwen, K. (2009). Survey of fishing gears and methods in Lower Taylor Creek area, Bayelsa state, Nigeria. World J. Fish and Marine Sci., 1(4) : 313-319.

Kumar, V. and Kumar, K. (2013). A preliminary study on fishing craft and gears in Dhaura reservoir, Uttarakhand. International Research Journal of Biological Sciences, 2(8) : 47-78.

Mathai, T. J. and George, N. A.(1972). A Note on the comparative catch efficiency of Nylon over Cotton Gillnets in reservoir fishing. Fish Technol., 20(2): 81-82.

Mohammed, O. M. (2012). A short review on : Fishing boats used in Sudan Freshwater Fisheries. Bull. Environ. Pharmacol. Life Sci., 1(6) : 93-99.

Sakhare, V. B. (2007). Fisheries and Limnology. Narendra Publishing House, New Delhi.

Srivastava, Gopalji (2002). Fishes of U. P. \& Bihar : $4^{\text {th }}$ edn. Vishwavidyalaya Prakashan, Varanasi, p. 207.

Sugunan, V. V. (1995). Reservoir Fisheries of India. Fisheries Aquaculture Department, FAO Corporate Documentary Repository, FAO Rome.

Verghese, M. D.; George, V. C.; Khan, A. A. and Iyer, H. (1982). Shore seines for reservoirs, Part-II. Studies on Optimal Mesh Size, Fish Technol., 20(2): 97-100 